\title{
ANALYSIS OF THE EFFECT OF TRANSFORMATIONAL LEADERSHIP, COMMUNICATION AND MOTIVATION ON EMPLOYEE PERFORMANCE
}

\author{
Agus Susanto \\ Institut Bisnis IT\&B Sumatera Utara, Indonesia \\ E-mail: agussuanto@yahoo.com
}

\begin{abstract}
This study aims to examine the effect of transformational leadership and communication on employee performance with work motivation as an intervening variable at the Dr Wahidin Sudirohusodo National Higher Education Foundation, Medan. The number of samples in this study were 76 respondents using simple random sampling method. This type of research is quantitative research using path analysis techniques and questionnaire data. Path analysis hypothesis test is done by using multiple linear analysis, classical assumption test and intervention test. Based on the results of research with hypothesis testing, the variables of transformational leadership and communication partially have a positive and significant effect on work motivation. The transformational leadership and communication variables partially show a significant effect on employee performance. Transformational leadership on employee performance with work motivation as an intervening variable has a positive and significant indirect effect and there is an influence of communication on employee performance with work motivation as an intervening variable. The variables of transformational leadership and communication have a simultaneous effect on work motivation. The variables of transformational leadership, communication, and work motivation simultaneously affect employee performance with a coefficient of determination of $87.8 \%$ which means that the variables of transformational leadership, communication and work motivation can explain employee performance as much as $87.8 \%$ and the remaining $12,2 \%$ is explained by other variables such as discipline, commitment, compensation and others. Transformational leadership and communication variables have a simultaneous effect on work motivation. The variables of transformational leadership, communication, and work motivation simultaneously affect employee performance with a coefficient of determination of $87.8 \%$ which means that the variables of transformational leadership, communication and work motivation can explain employee performance as much as $87.8 \%$ and the remaining $12.2 \%$ is explained by other variables such as discipline, commitment, compensation and others. Transformational leadership and communication variables have a simultaneous effect on work motivation. Transformational leadership variables, communication.
\end{abstract}

Keywords : Transformational Leadership, Employee Performance, Communication, Work Motivation

\section{INTRODUCTION}

Human resources are the main component in an organization which is an active planner and actor in every organizational activity. They have heterogeneous thoughts, feelings, desires, status and educational background, age, gender which are brought to an organization to collaborate to achieve goals. The strength of an organization lies in its human resources, not in its systems, technology, procedures, or funding sources. So, the functioning of the parts in the organization depends on the ability of the people in the organization concerned to move them towards the achievement of the goals that have been set. Quality human resources will develop high performance for the organization. Employee performance is the result of work achieved by someone in carrying out tasks 
in accordance with their responsibilities. Jobs that match the job description are expected to be completed on time and meet quality and quantity standards. Employees can work well if they have high performance so that they can produce good work. With high employee competence, it is expected that organizational goals can be achieved.

Transformational leadership is a leader who stimulates and inspires (changes) subordinates to achieve extraordinary results. A transformational leader can bring about major changes in both followers and organizations. It is not only leadership that needs to be considered, but the communication that exists between good leaders and subordinates is also something that must be considered. According to Bass in Yukl, (2015: 301) states transformational leadership as a leader who has the power to influence subordinates in certain ways. By implementing transformational leadership, subordinates will feel trusted, valued, loyal and respectful to their leaders. In the end, subordinates will be motivated to do more than expected.

Communication in an organization is an important factor in undergoing interaction with each other, if there is no communication, all individuals in the organization cannot know what they should do for the organization, leaders cannot receive information input and providers cannot give instructions.

Motivation can be said to be a driving force from within and within the subject to carry out certain activities in order to achieve a goal. In fact, motivation can be said to be an internal condition (preparedness). Motivation can be seen as a change in energy in a person which is characterized by the emergence of feelings, and is preceded by a response to a goal. Motivation is the basic drive that moves a person or desire to devote all his energy to a goal. With motivation and performance appraisal, organizational goals can be achieved and personal goals can also be achieved. Giving motivation to someone is a link that starts with a need, creates a desire, causes action, and produces a decision. From the various stages of giving motivation, the main factor is the need and direction of behavior. Giving motivation must be directed at achieving organizational goals. Only with clarity of purpose, all personnel involved in the organization can easily understand and implement it.

NS National Higher Education Foundation Dr. Wahidin Sudirohusodo concerned in the field of education, especially primary and secondary education, both junior high and general. This foundation has been around for a long time and is a private foundation. In the course of its activities, the Foundation has a vision and mission to be achieved in the future. Based on the problems above, the authors are interested in analyzing the effect of transformational leadership and communication on employee performance (Study at the Dr. Wahidin Sudirohusodo College Foundation).

\section{RESEARCH METHOD}

The method used in this study was done through data collection by questionnaires and testing using path analysis. This study uses primary data. Where the primary data in the form of questionnaires and interviews conducted to 76 respondents. This research was conducted from April to July 2018 at the Dr. National Higher Education Foundation. Wahidin Sudirohusodo Medan.

\section{RESULTS AND DISCUSSION}

\subsection{Results of Observation Using Questionnaire The Effect of Transformational Leadership and Communication on Employee Performance}

This research was conducted on employees of the National Higher Education Foundation Dr. Wahidin Sudirohusodo Medan with a research sample of 76 people. 
Table 1. Descriptive Analysis Results

\begin{tabular}{|c|c|c|c|c|c|c|c|c|c|c|c|}
\hline \multirow{3}{*}{ No } & \multirow{3}{*}{ Penyataan } & \multicolumn{10}{|c|}{ Alternatif Jawaban } \\
\hline & & \multicolumn{2}{|r|}{ SS } & \multicolumn{2}{|r|}{ S } & \multicolumn{2}{|c|}{$\mathrm{R}$} & \multicolumn{2}{|c|}{ TS } & \multicolumn{2}{|c|}{ STS } \\
\hline & & $\mathrm{F}$ & $\%$ & $\mathrm{~F}$ & $\%$ & $\mathrm{~F}$ & $\%$ & $\mathrm{~F}$ & $\%$ & $\mathrm{~F}$ & $\%$ \\
\hline 1 & Kreatif & 38 & 50,00 & 32 & 42,11 & 0 & 0,00 & 6 & 7,89 & 0 & 0,00 \\
\hline 2 & Masukan & 40 & 52,63 & 30 & 39,47 & 0 & 0,00 & 6 & 7,89 & 0 & 0,00 \\
\hline 3 & $\begin{array}{l}\text { Bertanggung } \\
\text { jawab }\end{array}$ & 38 & 50,00 & 31 & 40,79 & 0 & 0,00 & 7 & 9,21 & 0 & 0,00 \\
\hline 4 & Konflik & 42 & 55,26 & 31 & 40,79 & 0 & 0,00 & 3 & 3,95 & 0 & 0,00 \\
\hline 5 & Kerja sama & 39 & 51,32 & 29 & 38,16 & 0 & 0,00 & 8 & 10,53 & 0 & 0,00 \\
\hline 6 & $\begin{array}{l}\text { Keinginan } \\
\text { menjadi seorang } \\
\text { pemimpin }\end{array}$ & 42 & 55,26 & 32 & 42,11 & 0 & 0,00 & 2 & 2,63 & 0 & 0,00 \\
\hline 7 & $\begin{array}{l}\text { Selamat melatih } \\
\text { tim }\end{array}$ & 35 & 46,05 & 30 & 39,47 & 0 & 0,00 & 11 & 14,47 & 0 & 0,00 \\
\hline \multicolumn{2}{|c|}{ Total } & & 360,53 & & 282,89 & & 0,00 & & 56,58 & & 0,00 \\
\hline \multicolumn{2}{|c|}{ Rata-rata } & & 51,50 & & 40,41 & & 0,00 & & 8,08 & & 0,00 \\
\hline
\end{tabular}

Sumber: Data diolah dari hasil penelitian, 2019

Based on table 1, it can be seen that the average respondents answered strongly agree (SS) as much as $51.50 \%$, answered agree (S) at $40.41 \%$, in doubt (R) $0.00 \%$ and disagree (TS) $80.08 \%$ and strongly disagree (STS) similarly dubious (R). Of all respondents' answers, there are $91.91 \%$ of respondents who chose the answer strongly agree and the answer agrees where the percentage of answers between an assessment score of 80 to 100 with a very good category. This highlights that employees like to come up with creative ideas in the workplace and are passionate about taking on the task of training a team to complete a specific mission. While overall, the total respondents' answers as many as $8.08 \%$ of respondents answered disagree. This explains that there are still weaknesses related to these problems,

Table 2. Results of Multiple Linear Regression Analysis

\begin{tabular}{|c|c|c|c|c|c|c|}
\hline & \multirow{2}{*}{ Model } & \multicolumn{2}{|c|}{$\begin{array}{c}\text { Koefisien Tidak } \\
\text { Standar }\end{array}$} & \multirow{2}{*}{$\begin{array}{c}\text { Koefisien } \\
\text { Standar } \\
\text { Beta }\end{array}$} & \multirow{2}{*}{$\mathrm{T}$} & \multirow{2}{*}{$\begin{array}{c}\text { Tanda } \\
\text { tangan }\end{array}$} \\
\hline & & B & $\begin{array}{c}\text { Std. } \\
\text { Kesalahan }\end{array}$ & & & \\
\hline & (Konstan) & 7.840 & 1,910 & & 4.105 &, 000 \\
\hline 1 & $\begin{array}{l}\text { Kepemimpinan } \\
\text { Transformasional }\end{array}$ & , 155 & ,031 & ,354 & 4,990 & ,000 \\
\hline & Komunikasi & ,392 & ,044 & 632 & 8.920 & ,000 \\
\hline
\end{tabular}

A. Variabel Dependen: Motivasi Kerja

Sumber: Data diolah dari hasil penelitian, 2019

Based on table 2, it can be seen that the constant value is 7.840 , meaning that if transformational leadership (X1) and communication (X2) is 0 (zero), then the value of work motivation $(Z)$ is 7.840 . Every time there is an increase in the quality of transformational leadership, the increase in work motivation will be followed by 0.155 . Improving the quality of communication will be followed by an increase in work motivation of 0.392 . 
Analysis Of The Effect Of Transformational Leadership, Communication And Motivation On Employee Performance

Agus Susanto

Table 3. Test Results of the Effect of Transformational Leadership, Communication and Work Motivation on Employee Performance

\begin{tabular}{|c|c|c|c|c|c|}
\hline \multirow{2}{*}{ Model } & \multicolumn{2}{|c|}{ Koefisien Tidak Standar } & \multirow{2}{*}{$\begin{array}{c}\begin{array}{c}\text { Koefisien } \\
\text { Standar }\end{array} \\
\text { Beta }\end{array}$} & \multirow{2}{*}{$\mathrm{T}$} & \multirow{2}{*}{$\begin{array}{l}\text { Tanda } \\
\text { tangan. }\end{array}$} \\
\hline & $B$ & $\begin{array}{c}\text { Std. } \\
\text { Kesalahan }\end{array}$ & & & \\
\hline (Konstan) & $-9,412$ & 2.113 & & -4.455 & 000 \\
\hline $\begin{array}{l}\text { Kepemimpinan } \\
1 \text { Transformasional }\end{array}$ & , 077 & ,036 & , 107 & 2.154 & ,035 \\
\hline Komunikasi & ,347 & ,063 & ,338 & 5.479 & ,000 \\
\hline Motivasi kerja & ,989 &, 117 &, 598 & 8.473 &, 000 \\
\hline
\end{tabular}

A. Variabel Dependen: Kinerja Karyawan

Sumber: Data diolah dari hasil penelitian, 2019

Based on table 3, it can be seen that the constant value of -9.412 means that if the transformational leadership (X1) and communication (X2) is 0 (zero), there is a tendency for the employee performance value $(\mathrm{Y})$ to decrease by -9.412 . The regression coefficient for transformational leadership is 0.077 and is positive, meaning that if transformational leadership has increased by one unit, the employee's performance value will increase by 0.077 , cateris paribus. The communication regression coefficient is 0.347 and has a positive direction, meaning that if communication increases by one unit, the employee performance value will increase by 0.347 , cateris paribus.

\subsection{The effect of transformational leadership on work motivation}

Based on the results of the analysis, the tcount value is $4.990>$ ttable 1.666 and the significance value is $0.000<0.05$. The value of the regression coefficient $(B)$ and tcount use a significant level of 0.05 . It means $\mathrm{Ha}$ is accepted. HO is rejected, so it can be concluded that the results of the transformational leadership variable have a positive and significant effect on the work motivation variable, meaning that the better the existing transformational leadership, the employee's work motivation will increase. On the other hand, the leadership of the National Higher Education Foundation, Dr. Wahidin Sudirohusodo, Medan, always provides direction or motivation to his subordinates to improve themselves, both leaders and employees.

\subsection{The Effect of Communication on Work Motivation}

Based on the results of the analysis, the tcount value is $8.920>$ ttable 1.666 and the significance value is $0.000<0.05$. The regression coefficient $(B)$ and tcount use a significant level of 0.05. It means $\mathrm{Ha}$ is accepted. $\mathrm{H} 0$ is rejected, so it can be concluded that the results of the communication variable have a positive and significant effect on the motivation variable. National Higher Education Foundation Dr. Wahidin Sudirohusodo Medan has provided information to members of the organization about the goals and policies of the organization, which has implemented communication between superiors and subordinates to interact properly starting from information, messages and suggestions and suggestions. So that organizational communication at the National Higher Education Foundation Dr. Wahidin Sudirohusodo Medan has a positive side to work motivation.

\subsection{The Effect of Transformational Leadership and Communication on Work Motivation}

Based on the results of the analysis, Fcount is 75.570, while Ftable (2;73) from the distribution table and the significance value is 0.000. This means that Fcount > Ftable or $75.570>$ 
3.12 and the value is significantly smaller than the alpha value with 0.05 , significant $<(0.000<0.05)$. $\mathrm{So}, \mathrm{Ha}$ is accepted and $\mathrm{HO}$ is rejected. This means that the variables of transformational leadership and communication simultaneously affect the variable of work motivation. This explains that the staff of the National Higher Education Foundation, Dr. Wahidin Sudirohusodo Medan has a charismatic leader who can inspire, stimulate intellectual and trust employees with individual and group attention. With regard to organizational communication variables,

Leadership is an important factor in providing direction to employees. Especially now that everything is completely open, so the leadership needed is leadership that can empower employees. To improve employee performance both quantitatively and qualitatively as well as timeliness in work, support from company leaders is needed, especially regarding the trust of subordinates to the leadership, clarity of subordinates to the vision and mission of the leadership and awareness of subordinates to the direction of the leadership, attention of leaders to the morale of subordinates, the ability of leaders to increase the confidence of subordinates, guidance in improving the ability of subordinates to solve problems and be innovative and support the leader in increasing the knowledge of subordinates, and also the clarity of the leader.

\subsection{The Effect of Transformational Leadership on Employee Performance}

The results of this study obtained a tcount value of $2.154>$ ttable 1.666 and a significance value of $0.035<0.05$. The regression coefficient ( $($ ) and tcount use a significant level of 0.05 . Then $\mathrm{Ha}$ is accepted and $\mathrm{HO}$ is rejected, so it can be concluded that the results of the transformational leadership variable have a positive and significant effect on the employee performance variable. These results are similar to research conducted by Agustina Ritawati (2013). Agustina stated that the transformational leadership style has a positive effect on the performance of insurance employees by taking an interpersonal approach to subordinates, so that subordinates feel happy with the way the leader provides direction to achieve higher performance.

\subsection{The Effect of Communication on Employee Performance}

The results of the analysis showed that the tcount value was 5,479>ttable 1,666 and the significance value was $0.000<0.05$. The regression coefficient $(B)$ and tcount use a significant level of 0.05. This means that $\mathrm{Ha}$ is accepted and $\mathrm{H} 0$ is rejected, so it can be concluded that the results of the communication variable have a positive and significant effect on the employee performance variable. National Higher Education Foundation Dr. Wahidin Sudirohusodo Medan has provided information to members of the organization about the goals and policies of the organization, which has been carried out by organizational communication between superiors and subordinates. They can interact well starting from information, messages and advice and suggestions. So that organizational communication at the National Higher Education Foundation Dr. Wahidin Sudirohusodo Medan.

\subsection{The Effect of Motivation on Employee Performance}

The results showed that the tcount value was $8.473>$ ttable 1.666 and the significance value was $0.000<0.05$. The regression coefficient $(B)$ and tcount use a significant level of 0.05 . This means that $\mathrm{Ha}$ is accepted and $\mathrm{H} 0$ is rejected, so it can be concluded that the results of the work motivation variable have a positive and significant effect on the employee performance variable. Employees like challenges at work and the challenge of solving a problem quickly. Employees always try to evaluate themselves after carrying out their work in order to improve their performance. 


\subsection{The Influence of Transformational Leadership, Communication and Work Motivation on Employee Performance}

Based on the results of the analysis, Fcount is 181.552, while Ftable $(3 ; 73)$ from the distribution table is 2.72 and the significance value is 0.000 . This means that Fcount $>$ Ftable or $181.552>2.72$ and the significant value is less than the alpha value of 0.05 , significant $<(0.000<$ 0.05). So Ha is accepted and $\mathrm{HO}$ is rejected. This means that the variables of transformational leadership, communication and work motivation have a simultaneous effect on employee performance variables. This highlights that the employees of the National Higher Education Foundation Dr. Wahidin Sudirohusodo has a leader who has a reaction to critical things, example, charisma, inspirational personality, intellectual stimulation and employee trust with attention both individually and in groups. As for the communication variable, it shows that communication has a simultaneous effect on employee performance. This explains that the staff of the National Higher Education Foundation, Dr. Wahidin Sudirohusodo Medan can use excellent communication according to indicators such as providing information about assignments, performance results to subordinates, subordinates easily providing information as input and consulting with superiors if there are obstacles, overcoming problems and equality in communication between work groups. All independent variables run well on the dependent variable simultaneously, so that employee performance has increased significantly. Wahidin Sudirohusodo Medan can use excellent communication according to indicators such as providing information about assignments, performance results to subordinates, subordinates easily providing information as input and consulting with superiors if there are obstacles, overcoming problems and equality in communication between work groups. All independent variables run well on the dependent variable simultaneously, so that employee performance has increased significantly. Wahidin Sudirohusodo Medan can use excellent communication according to indicators such as providing information about assignments, performance results to subordinates, subordinates easily providing information as input and consulting with superiors if there are obstacles, overcoming problems and equality in communication between work groups. All independent variables run well on the dependent variable simultaneously, so that employee performance has increased significantly.

\section{CONCLUSION}

From the research conducted, it was found that the variables of transformational leadership, work motivation and employee performance were in the very good category, while communication was in the good category at the Dr Wahidin Sudirohusodo National Higher Education Foundation, Medan. Based on the results of the partial hypothesis test ( $t$ test), the transformational leadership variable has a positive and significant effect on work motivation. The communication variable has a positive and significant effect on work motivation. The transformational leadership variable has a positive and significant effect on employee performance. The communication variable has a positive and significant effect on employee performance. The work motivation variable has a positive and significant effect on employee performance and simultaneously or the $\mathrm{F}$ test, transformational leadership and communication have a positive and significant effect on employee performance through work motivation at the Dr. National Higher Education Foundation. Wahidin Sudirohusodo Medan. Based on the results of path analysis, it was found that transformational leadership variables through intervening variables, especially work motivation, had more influence on employee performance than the direct influence of transformational leadership on employee performance. Communication through intervening variables, specifically work motivation has more influence on employee performance than direct communication affects employee performance, with a coefficient of determination (R2) of $87.8 \%$ which means that the variables of transformational leadership, communication and work motivation can explain employee performance as much as 87 respondents. 
Leaders are able to convey the company's vision to employees by inspiring them to always be optimistic in achieving goals and providing personal support to train employees in carrying out their duties and good cooperation between colleagues and superiors and fully responsible for the work desk given. Each employee designs a work plan in advance so that every job can be done on time and with the support of the leadership so that the results obtained are more optimal.

\section{REFERENCE}

Brigham, Eugene, F. 2011. Manajemen Keuangan. Erlangga, Jakarta

Danim, Sudarwan, 2012. Kepemimpinan Pendidikan, Alfabeta, Bandung 2013, Menjadi Komunitas Belajar: Transformasional

Kepemimpinan dalam Komunitas Organisasi Pembelajaran, Bumi Aksara, Jakarta

Dessler, Gary, 2011. Manajemen Sumber Daya Manusia, Edisi 10, Indeks, Jakarta

Emad, dkk. 2014. Pentingnya Kepemimpinan dalam Peningkatan Produktivitas Konstruksi. Jurnal Penelitian Lanjutan Global Studi Manajemen dan Bisnis, Vol. 3, no.3, hal: 114-125

Erriani K. 2018. Hubungan Motivasi Kerja dengan Kinerja Pustakawan Bidang Pertanian di Kementerian Pertanian. Skripsi Institut Pertanian Bogor. Jurnal Penyuluhan, Maret 2018 No. 14 Vol. 1

Fattah, Nanang, 2014. Yayasan Manajemen Pendidikan, PT Remaja Rosdakarya, Bandung.

Febryantahanuji, 2017, Pengaruh Kepuasan Kerja dan Komunikasi Terhadap Komitmen Organisasi dengan Kepemimpinan Sebagai Variabel Moderasi Pada Stekom Semarang. Jurnal Nusamba, Vol.2, No.1

Haryani. 2010. Analisis Pengaruh Komunikasi, Motivasi, dan Kepemimpinan Terhadap Kepuasan Kerja Dalam Meningkatkan Kinerja Karyawan PT Arisa Mandiri Pratama,Jurnal Manajemen dan Kewirausahaan, volume 13.

Hasibuan, Melayu. 2008. Dasar Manajemen, Pengertian, dan Masalah. PT Bumi Aksara, Jakarta

Kuswana, Wowa S, 2013. Manajemen Kinerja, PT. Raja Grafindo Persada, Jakarta

Mangkunegara, AP 2010, Manajemen Sumber Daya Manusia, Edisi Rev., Penerbit Bina Aksara, Jakarta 2012, Manajemen Sumber Daya Manusia Perusahaan, Remaja Rosdakarya, Bandung

Marshall Sashkin \& Molly G. Sashkin, 2011. Prinsip Kepemimpinan, Erlangga, Jakarta

Nyowani. Tri Wahyuni, 2014, Pengaruh Motivasi dan Pelatihan Kerja Terhadap Kinerja Pegawai pada BPRS Karya Mugi Sentosa Trenggalek dan BPRS Tanmiya Artha Kediri IAIN Tulungagung.

Richard L. Hughes, dkk, 2012, Kepemimpinan: Memperkaya Pelajaran dari Pengalaman, Edisi 7, Salemba Humanika, Jakarta 
Analysis Of The Effect Of Transformational Leadership, Communication And Motivation On Employee Performance

Agus Susanto

Rivai, Veitzal \& Ella Jauvani Sagala. 2011. Manajemen Sumber Daya Manusia Perusahaan. PT. Raja Grafindo Persada. Jakarta.

Robbins, Stephen P, \& Timothy A Hakim. 2014. Perilaku Organisasi, Edisi Ketigabelas. Pearson Prentice Hall, New Jersey

Sandy Marta, Muhammad. 2015. Karakteristik Pekerjaan dan Kinerja Dosen Berprestasi di UIN Sunan Gunung Djati Bandung: Komitmen Organisasi Sebagai Variabel Moderating. Skripsi di Universitas Widayatama, Bandung: Tidak Dipublikasikan.

Santoso, S.2010. Statistik Multivariat; Konsep dan Aplikasi dengan SPSS. Jakarta: PT Elex Media Komputindo

Sedarmayanti. 2011. Manajemen Sumber Daya Manusia, Reformasi Birokrasi dan Manajemen Pegawai Negeri Sipil (cetakan kelima). PT Refika, Bandung

Simamora, Wawan, 2016. Manajemen Sumber Daya Manusia, STIE YKPN, Yogyakarta.

Sugiyono. 2017. Statistik untuk Penelitian. CV Alfabeta, Bandung

Sunyoto, Danang. 2012.Sumber daya manusia Manajemen. Pusat Layanan Penerbitan Akademik (CAPS), Yogyakarta.

2013, Teori, Kuesioner, dan Analisis Data Sumber Daya Manusia (Praktek Penelitian), Pusat Layanan Penerbitan Akademik (CAPS), Yogyakarta.

Supardi, dan Anwar Syaiful, 2012, Dasar-dasar Perilaku Organisasi, UII Pres, Yogyakarta.

Sutrisno, Edy. 2011.Sumber daya manusia Manajemen Kencana, Jakarta

Suyadi. 2013. Strategi Pembelajaran Pendidikan Karakter. Remaja Rosdakarya. Bandung

Umam, Khaerul, 2012. Perilaku Organisasi, Pustaka Setia, Bandung

Veithzal Rivai. 2014.Manajemen Sumber Daya Manusia untuk Perusahaan, Edisi 6, PT. Raja Grafindo Persada, Depok

Yukl, Gary, 2015. Kepemimpinan dan Organisasi, Edisi 5, Indeks , Jakarta 